店 况

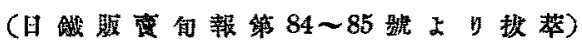

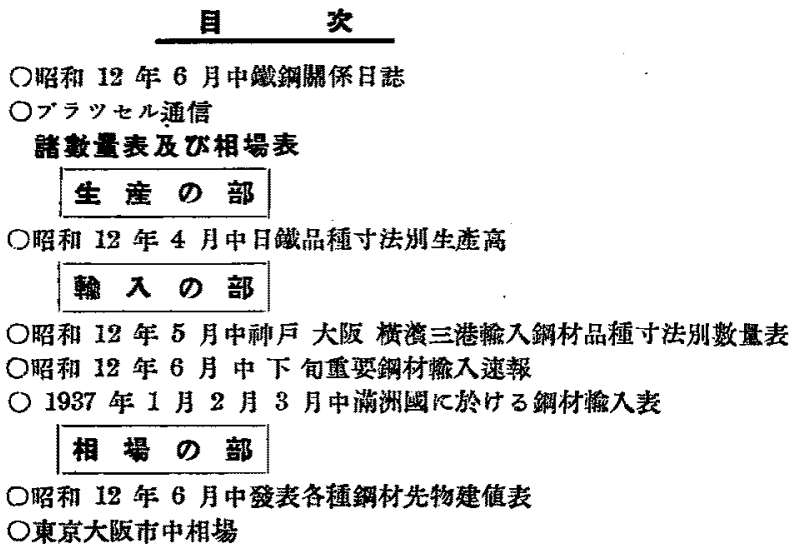

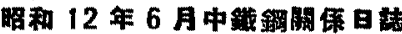

1 日 租閣 力大命近街公に降る。

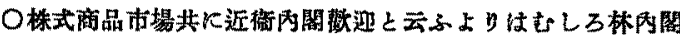

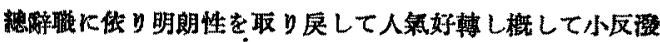
を示した。

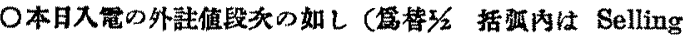
price)

Bar base 11-18-6 (12-0-0) Angle base 11-18-6 (120-0) Plate base 13-16-0 (14-10-0)

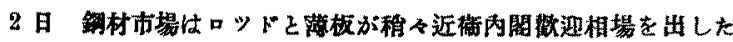

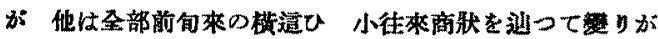
小かた。

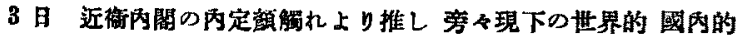

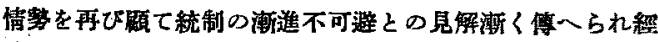

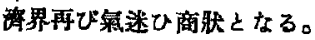

○アメリカに於てッェップ・ポーマリン法 (Export Trade

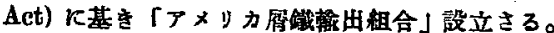

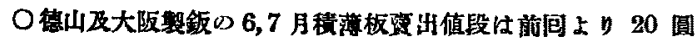
乃至 35 圆方引下げたりと。

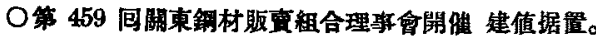

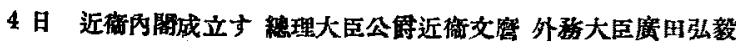
內腬大臣馬場筷一 大藏大臣賀屋興宣 交部大臣安茾英二

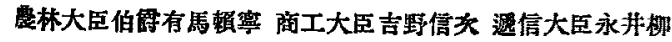
太郎 践道大臣中島知久平 拓雅大臣大谷尊由 隆軍大臣杉

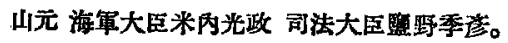

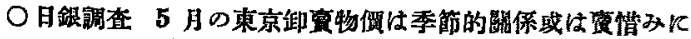

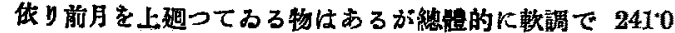
と前月に比し 2 分 8 厘方下落した 銅は新月に比し 103 \%の下落なりを。

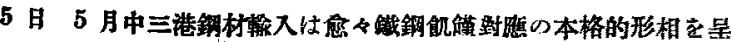
し 7 蕺 5,700t，几澾した。

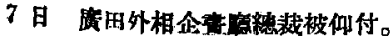

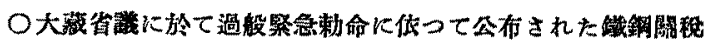

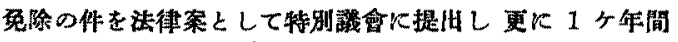

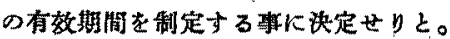

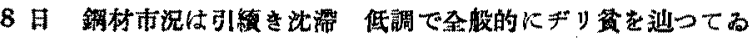
3 。

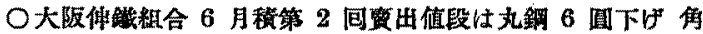

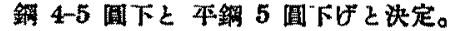

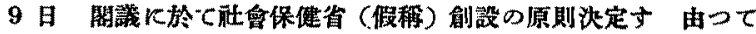

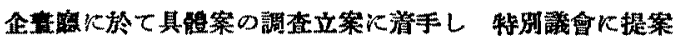
する东となった。

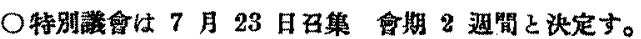

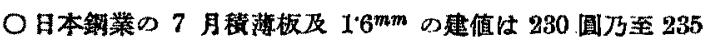
圆見常と決定せりと。

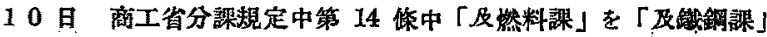

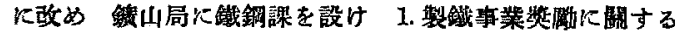

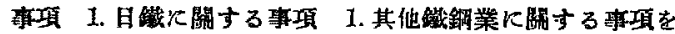
管掌せしむる事となつた。

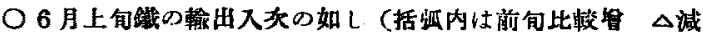
單位 1,000 圆)

稀出 $2,781(\triangle 949)$ 輸入 $19,838(4,192)$

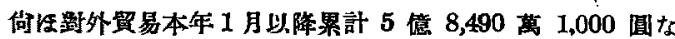
ろを以て上牛期入超は 6 㙁測必至と見らる。

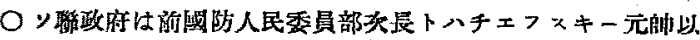

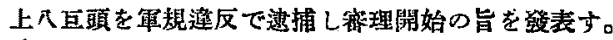

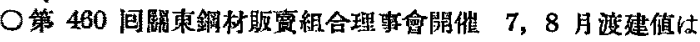
据簿。

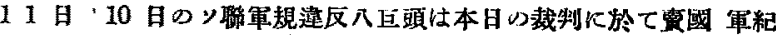

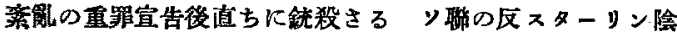

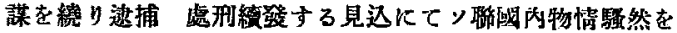
傅一らる。

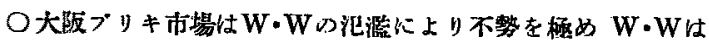
遂に 30 圆割れを示現す。 


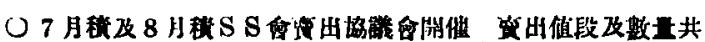
大触前间同拣儿決定。

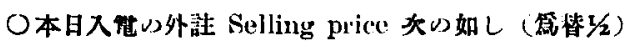

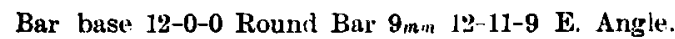
base, Large Angle, Joist \& Channel $m m$ size $12-0-0$ Plate base 13-19-6 Steel Sheet $322_{n m}$ 14-14-6 2'3 $3 m$ 14-2-6 $1.6 n$ 14-12-6

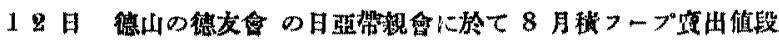
は28圆乃至 25 圆方の值下げと讨定した模粎である。做

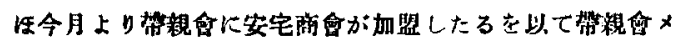

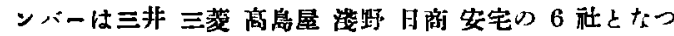
た。

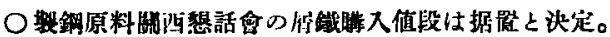

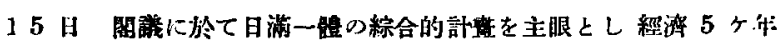

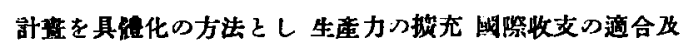

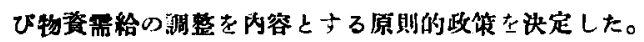

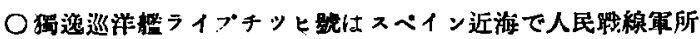

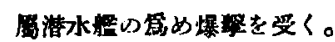

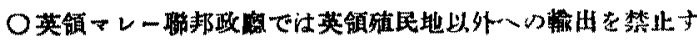
3旨發合士。

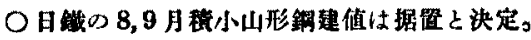

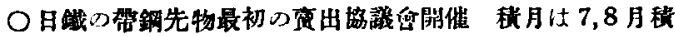

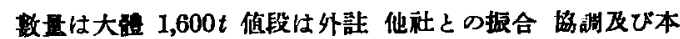
品の特殊事情等を彼是考虑して適度に决它さる。

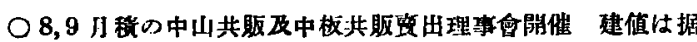
镇と决定。

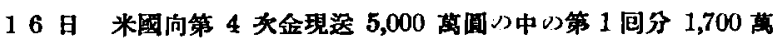

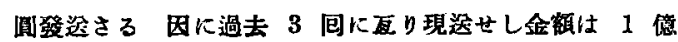
觖葛圆。

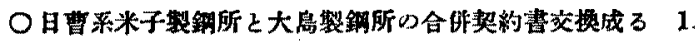

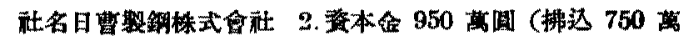
回) 3 .合拼日 12 月 1 日。

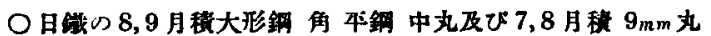
鋼建值は据㯰々決定。

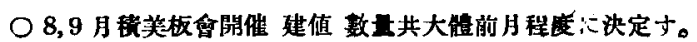

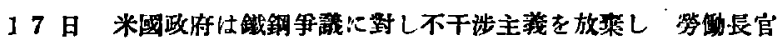
が琵業調停委員を任命せりとスティール株は初め4弗方 の念落を㴼じたが後前記情報を入れて反し接前日上り 3 弗 $1 / 4$ 高の 97 弗牛となる。

○8月皏三S 合建值は据路と決定。

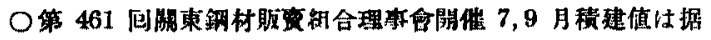
筧上汽定。

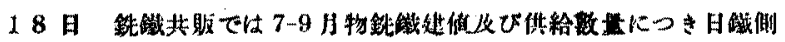

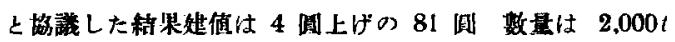
埥の 7 萬 7,000t 6 決定。

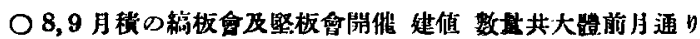
と決定。

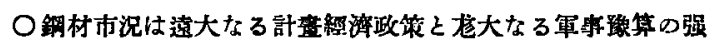
行と云ふ基調的な强材料る末だ遖感 反眣するに至らすし て時期的及其他の弱付料儿引担られて裉色不熄 東西共に 丸銅が 20 圆の關門次肉迫しつ」ある墑狀である。

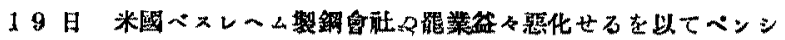

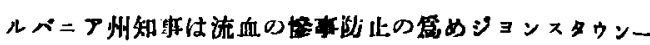
帮に戒校合を布きたりと。

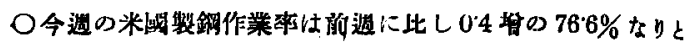
○スペイン反政府軍仕 19 日夜逐にヒルバオを占領す。

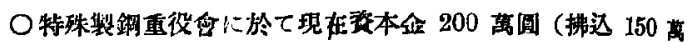

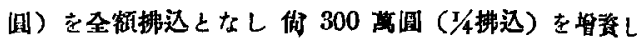

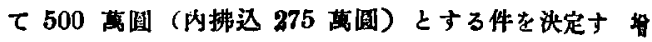

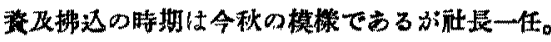

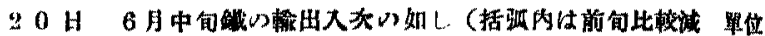
1,000 调)

榆出 $2,369(414)$ 猗 $入 18,430(1,408)$

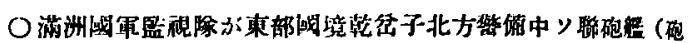

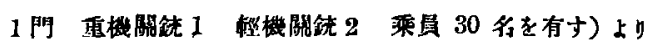

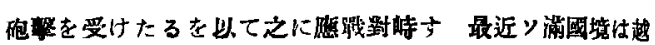

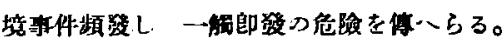

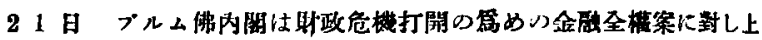

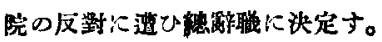

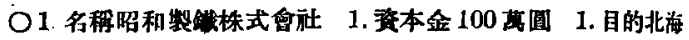

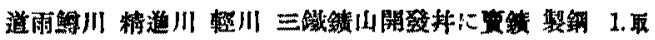

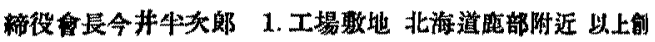
立跑曾に附路決定。

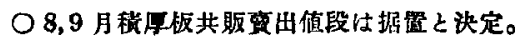

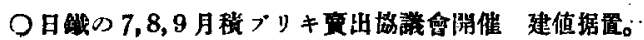

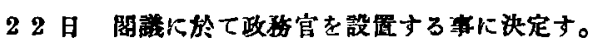

○佛國ショータン內閣成立す。

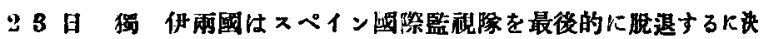
L. 英國政府火正式に脱退通知學書を手交した倘恃不下 涉委員會上りは脱退せずと。

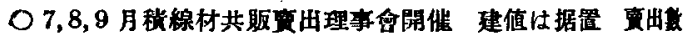
共は買手力自由申迈下振了求上決定。

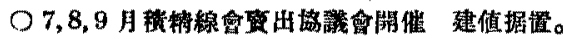

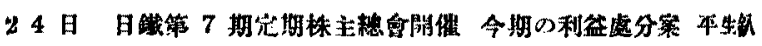

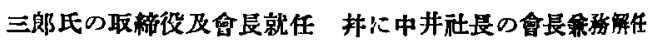
の作一致可决す。

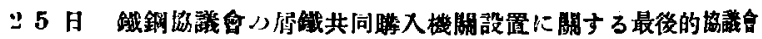

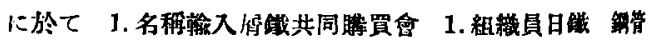

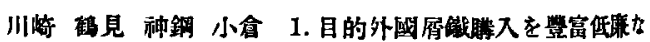

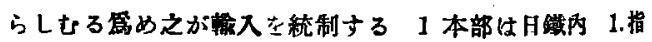

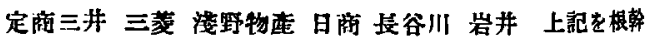
とする规約案可決さる。

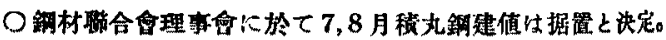

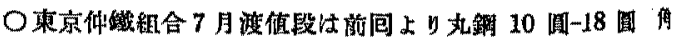

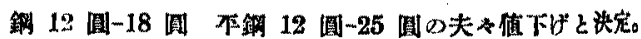

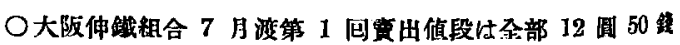
下けと決定。

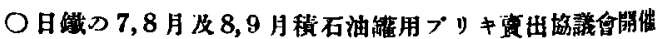
建值据置。

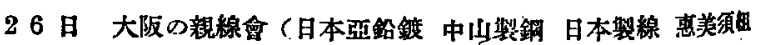

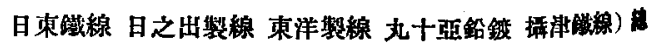
留に於て 7 月中は 3 割娍座晾守に決定す。

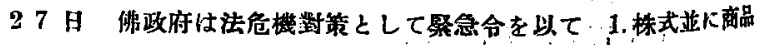

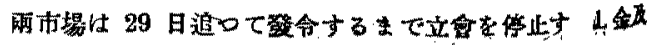




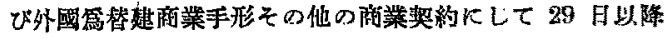

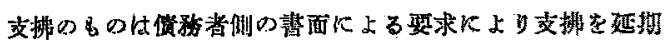
す百本索得と公布す。

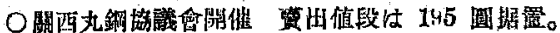

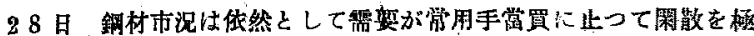

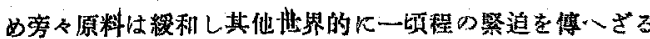

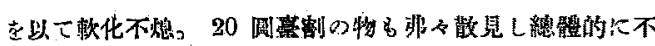
味沈溜を板けてるる。

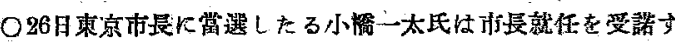

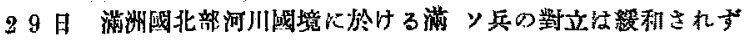

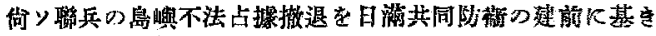
我方上りン挽常局儿要求す。

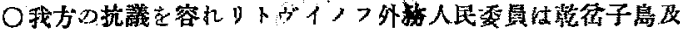

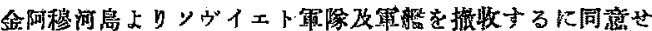
yと,

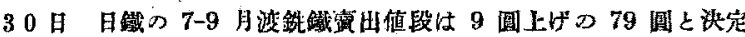

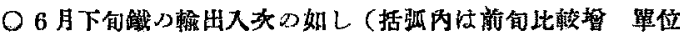
1,000 圆)

榆 出 $2,855(486$ ：榆 入 $95,593(7,163)$

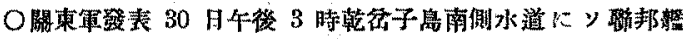

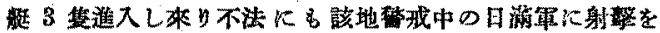

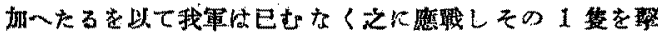

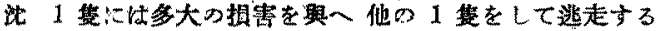

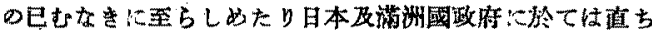
にン聯江對し筑重なる抗境を提出せり。

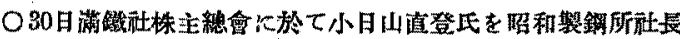
心選任す。

\section{6 月中笴替相埸}

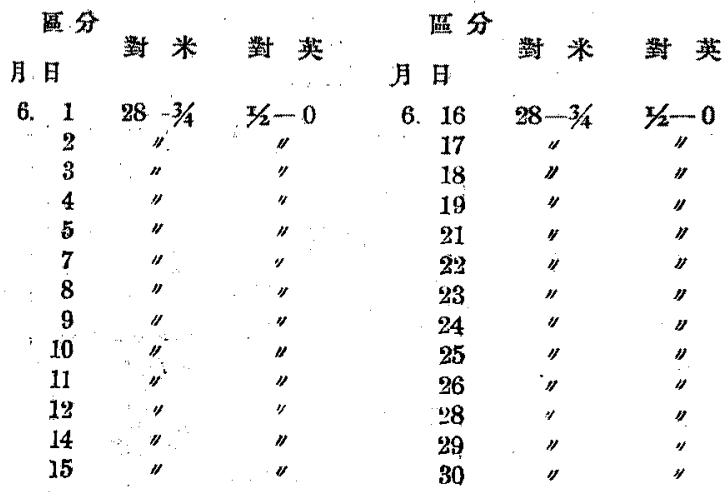

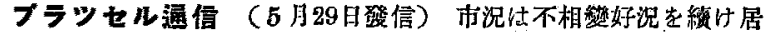

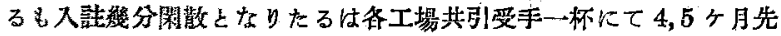
物ならで㤝見霄つかざるために外ならす候

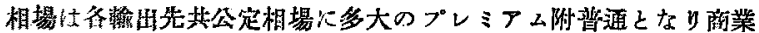

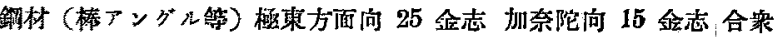

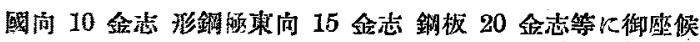

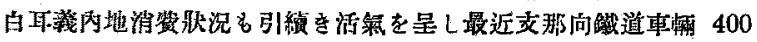

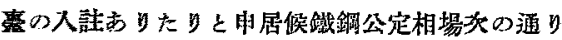

\begin{tabular}{|c|c|c|}
\hline & Export & Inland \\
\hline Bars (base) & \& 5-0-0 & fr. $\quad 975 \cdot 00$ \\
\hline Angles & $4-18-0$ & 975.00 \\
\hline Joist (B. S) & $4-18-0$ & 990.00 \\
\hline$"$ (N.S) & $4-17-6$ & $975^{\circ} 00$ \\
\hline Hoops (base) & $6-10-0$ & $1,450 \cdot 00$ \\
\hline Wire-rods & - & $1,050^{\circ} 0$ \\
\hline Plates $8 / 1 B^{\prime \prime}$ & $6-13-0$ & \\
\hline 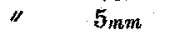 & - & $1,245^{\circ} 00$ \\
\hline Blooms 6" & $4-5-6$ & \\
\hline Billettes & $4-7-6$ & - \\
\hline Sheet bars & $4-8-6$ & - \\
\hline
\end{tabular}

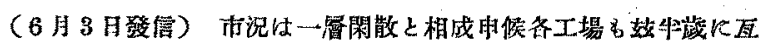

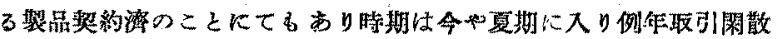

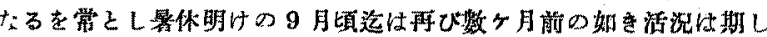
蜼了侯

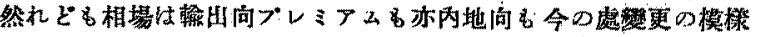
見え牙候

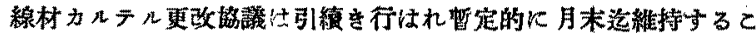

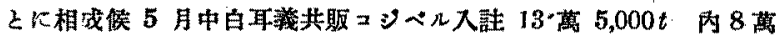

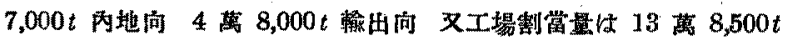

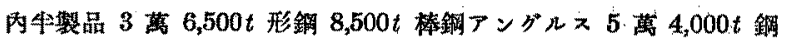

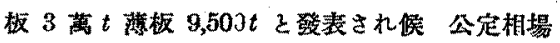

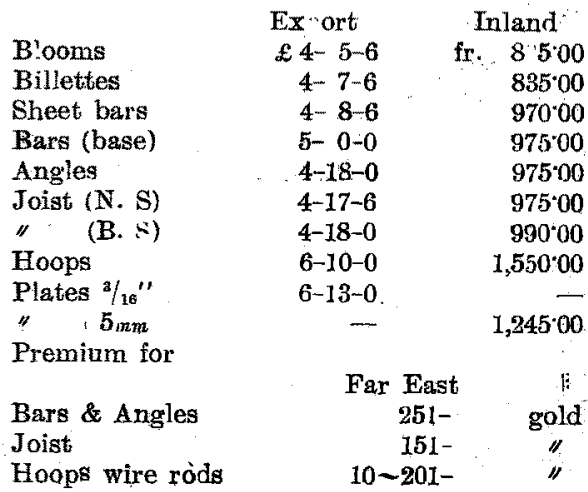


諸数量表及び相場表

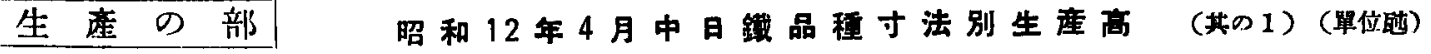

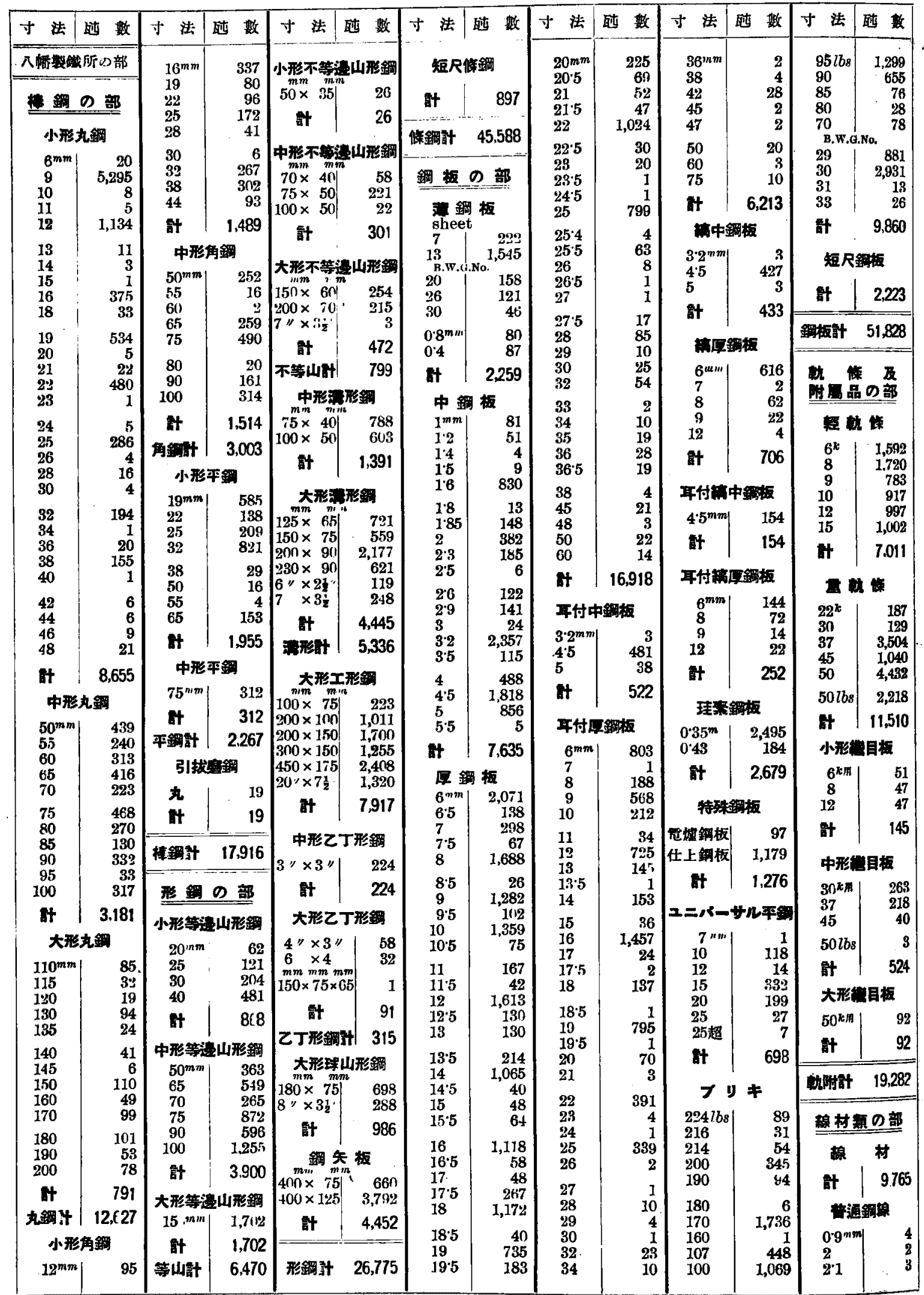


昭和 12 年 4 月中日鐵品種寸法別生座高（其の 2)(單位能)

\begin{tabular}{|c|c|c|c|c|c|c|c|c|c|c|c|c|c|}
\hline 寸法 & 醂 & 寸 法 & 酏数 & 寸法 & 殖粠 & 寸 法 & 醚 數 & 寸法 & 酰 数 & 寸法 & 酝 数 & 寸法 & 酝 数 \\
\hline \multicolumn{2}{|c|}{ 八蝶裂銭所の部 } & \multicolumn{2}{|c|}{ 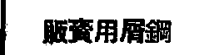 } & \multicolumn{2}{|c|}{ 三品 } & \multicolumn{2}{|c|}{ 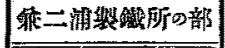 } & \multicolumn{2}{|c|}{ 窝士筑銅所の部 } & \multicolumn{2}{|c|}{ 大阪製䟼所の部 } & \multirow{6}{*}{$\begin{array}{l}12^{m m} \\
13 \\
14 \\
16 \\
19 \\
25 \\
32 \\
\text { 的 }\end{array}$} & \multirow{2}{*}{$\begin{array}{r}167 \\
1 \\
2\end{array}$} \\
\hline $2 \cdot 3$ & & 銅㞗 & $\begin{array}{l}1,619 \\
2,913\end{array}$ & 小斯 & 48 & \multicolumn{2}{|c|}{ 大形等遇山形鐥 } & \multirow{2}{*}{\multicolumn{2}{|c|}{ 小形丸鍓 }} & \multicolumn{2}{|c|}{ 小形丸鋼 } & & \\
\hline $\begin{array}{l}3 \\
3 \cdot 2\end{array}$ & 34 & 鼓 & $\begin{array}{l}8,913 \\
4,532\end{array}$ & 等山形 & 1,603 & $130^{m m}$ & 6 & $12^{m m}$ & & $12^{m m}$ & 746 & & $\begin{array}{r}72 \\
142 \\
\end{array}$ \\
\hline $\begin{array}{l}4 \\
45\end{array}$ & $\begin{aligned} 488 \\
9\end{aligned}$ & (1) & 舟网 & \multirow{2}{*}{\multicolumn{2}{|c|}{$\begin{array}{c}\text { 中形等䄈山形銅 } \\
\text { 一 粄 品 }\end{array}$}} & 150 & 4 & ${ }_{18}^{16}$ & $\begin{array}{l}1,478 \\
1,84\end{array}$ & $\begin{array}{l}16 \\
19\end{array}$ & $\begin{array}{l}693 \\
872\end{array}$ & & 2 \\
\hline & & 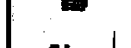 & 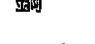 & & & & & 22 & 971 & 22 & 619 & & 2 \\
\hline 部 & 216 & 敛 & 835 & $\begin{array}{l}5 n^{m m m} \\
65\end{array}$ & $\begin{array}{l}275 \\
755\end{array}$ & \multicolumn{2}{|c|}{ 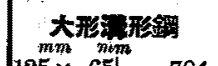 } & 25.5 & $\begin{array}{r}33 \\
33\end{array}$ & 20 & 454 & & 2,313 \\
\hline \multirow{2}{*}{\multicolumn{2}{|c|}{9,981}} & \multicolumn{2}{|c|}{ 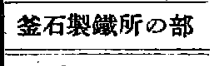 } & 75 & 780 & $\mid \begin{array}{lll}125 \times & 65 \\
1750 & 73\end{array}$ & 704 & 铻 & 41 & $\begin{array}{l}28 \\
32\end{array}$ & $\begin{array}{l}47 \\
47\end{array}$ & 规 格 & \\
\hline & & \multirow{2}{*}{\multicolumn{2}{|c|}{ 夳般鋼 }} & & 325 & $\mid$ & $\begin{array}{r}0.5 \\
25\end{array}$ & \multirow{2}{*}{\multicolumn{2}{|c|}{ 小形平銅 }} & $\begin{array}{l}36 \\
38\end{array}$ & $\begin{array}{l}346 \\
337\end{array}$ & $11^{m m}$ & 3 \\
\hline \multicolumn{2}{|c|}{ 基他金銝の部 } & & & & 2,359 & 郃 & 1.432 & & & 42 & 52 & 鯨 & 3 \\
\hline \multicolumn{2}{|c|}{ 特殊 鋼 } & 16 & 2,438 & $=. \equiv$ & 般品 & \multicolumn{2}{|c|}{ 大形工形銅 } & $\begin{array}{l}38^{m m} \\
50\end{array}$ & $\begin{array}{l}106 \\
284\end{array}$ & $\begin{array}{l}44 \\
48\end{array}$ & $\begin{array}{l}173 \\
163\end{array}$ & 短尺金 & 鋼板 \\
\hline 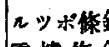 & & $\begin{array}{l}19 \\
22\end{array}$ & $\begin{array}{r}2,440 \\
552\end{array}$ & 許 & 279 & $100 \times \quad 75$ & 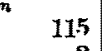 & 踣 & 12 & 其 他 & 155 & 計 & 511 \\
\hline 需譃攸 & & 25 & 545 & 虫等山俆 & 2,638 & 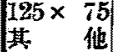 & $\begin{array}{l}2 \\
4\end{array}$ & 鼓 & 402 & 帠 & 4,715 & ミスロ & ロール \\
\hline 就 & i & $\begin{array}{l}38 \\
32\end{array}$ & $\begin{array}{l}263 \\
270\end{array}$ & 銅村誥 & 14,832 & 誄 & 121 & 小形スフ & リンタ & 小形平 & 平龬 & 酯 & 60 \\
\hline 罱 成 & 或品 & 44 & 147 & 鋭 & 片 & 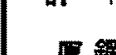 & & & & 25 & 103 & GT & 00 \\
\hline 通 & $\begin{array}{l}211 \\
0\end{array}$ & st & 6,898 & 一糈品 & 317 & If 釾 & & $\begin{array}{l}13 / 4 " \\
21 / 4\end{array}$ & $\begin{array}{l}89 \\
50\end{array}$ & $\begin{array}{l}26 \cdot 3 \\
3355\end{array}$ & $\begin{array}{r}118 \\
74\end{array}$ & 眅糞用 & 用眉金龬 \\
\hline 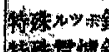 & & $\underset{12^{m m}}{=\text { 㩽 }}$ & & | 积品 & 2 & ${ }^{6 m}$ & $\begin{array}{r}207 \\
17\end{array}$ & $2 \%$ & 36 & $\begin{array}{l}35 \\
38\end{array}$ & $: \frac{121}{21}$ & 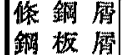 & $\begin{array}{r}85 \\
366\end{array}$ \\
\hline 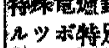 & & & $\begin{array}{l}11 \\
236 \\
78\end{array}$ & 针 & 319 & $\begin{array}{l}8 \\
9\end{array}$ & $\begin{array}{l}621 \\
484\end{array}$ & 短 & 7 & 40.3 & 58 & 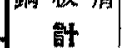 & 451 \\
\hline 迹度全 & & $\begin{array}{l}19 \\
22\end{array}$ & $\begin{array}{l}78 \\
46\end{array}$ & $\dot{*}-1$ & מאו & 10 & 339 & at & 182 & 405 & 64 & 金閶 & 埧 \\
\hline 8 & 248 & 25 & 33 & 二釉品 & $\begin{array}{l}4,198 \\
774\end{array}$ & 11 & 48 & 小形八 & 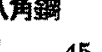 & 列7 & $\begin{array}{l}41 \\
65\end{array}$ & the & \\
\hline 其 & 地 ${ }_{510}$ & $\begin{array}{l}28 \\
32\end{array}$ & $\begin{array}{l}24 \\
34\end{array}$ & 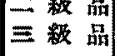 & $\begin{array}{l}774 \\
126\end{array}$ & 13 & $\begin{array}{r}1,2,15 \\
40\end{array}$ & $\begin{array}{l}16^{m m} \\
19\end{array}$ & $\begin{array}{r}45 \\
115\end{array}$ & 44 & 50 & at & 19,465 \\
\hline 唃 & 754 & 44 & 28 & 計 & 5,063 & $\frac{14}{15}$ & 19 & 25 & $\begin{array}{l}25 \\
22\end{array}$ & $\begin{array}{l}50 \\
65\end{array}$ & $\begin{array}{l}177 \\
202\end{array}$ & 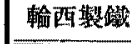 & 䪭所の部 \\
\hline 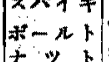 & & & 品 & 鏹 & 堵 & $\begin{array}{l}16 \\
17\end{array}$ & $\begin{array}{r}428 \\
2\end{array}$ & ${ }^{2}{ }^{\text {P }}$ & $\begin{array}{r}10 \\
217\end{array}$ & 针 & $\begin{array}{r}25 \\
1,144\end{array}$ & 珒 & 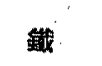 \\
\hline $\mid \begin{array}{l}x+\infty 1 \\
1\end{array}$ & 68 & t & 263 & 解 & 25.002 & $\begin{array}{l}18 \\
19\end{array}$ & $\begin{array}{r}3 \\
73\end{array}$ & 带 & 鋼 & | 中形等邀| & 屾形銅 & 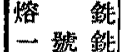 & $\begin{array}{r}21 \\
1,341\end{array}$ \\
\hline at & 3 & 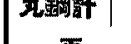 & 7,651 & 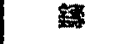 & 鍕 & 21 & 3 & $78^{\mathrm{mm}}$ & 26 & $50^{m m}$ & 325 & 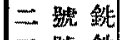 & 9,001 \\
\hline & & & & 竍 & 8 & 25 & 24 & 825 & 56 & $\begin{array}{l}80 \\
75\end{array}$ & 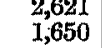 & 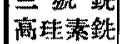 & $\begin{array}{r}9,450 \\
95\end{array}$ \\
\hline 基他野材指 & 計 1,679 & $38^{m m}$ & 463 & & & 6 & 178 & $\begin{array}{l}86 \\
89\end{array}$ & $\begin{array}{r}46 \\
143\end{array}$ & $\begin{array}{ll}90 & \\
{ }^{3} & \text { 他 }\end{array}$ & $\begin{array}{l}401 \\
115\end{array}$ & 䐠 $\quad$ 銶 & 326 \\
\hline 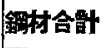 & 128,358 & 65 & 1,166 & 年 & 803 & 小现耳付 & 117 & 92 & 141 & 敦 & 5,112 & 計 & \begin{tabular}{|l|}
20,214 \\
\end{tabular} \\
\hline 锞 & 鐵 & 鲇 & 2,643 & 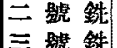 & $\begin{array}{r}523 \\
6083\end{array}$ & 㢵 & 3,831 & 95 & 73 & 耳付厚全 & 䤣龢板 & & \\
\hline 所 & 62,385 & 二趺 & & 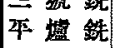 & $\begin{array}{r}6,085 \\
876\end{array}$ & & & $\begin{array}{l}98 \\
101\end{array}$ & $\begin{array}{r}45 \\
101\end{array}$ & $6^{m m}$ & 365 & & \\
\hline & \begin{tabular}{|l|}
77,641 \\
\end{tabular} & $38^{m m}$ & 26 & 㷘鈛 & 12,155 & & & 102 & 58 & 7 & & & \\
\hline & 56,897 & $\begin{array}{l}44 \\
50\end{array}$ & $\begin{array}{l}13 \\
76\end{array}$ & 䐠 $\quad$ 鉄 & 71 & & & $\begin{array}{l}104 \\
105\end{array}$ & $\begin{array}{l}103 \\
110\end{array}$ & $\begin{array}{l}8 \\
9\end{array}$ & $\begin{array}{r}584 \\
1,155\end{array}$ & & \\
\hline if 1 & | 136,873 & 65 & 87 & 鳞 & 20,511 & & & 敦 & $\begin{array}{r}110 \\
1,175\end{array}$ & 10 & 123 & & \\
\hline 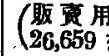 & 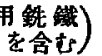 & 㩆 & 202 & & & & & 銅材計 & 6,884 & $\begin{array}{l}11 \\
12\end{array}$ & $\begin{array}{r}17 \\
473\end{array}$ & & \\
\hline 銅 & 地 & 三級 & 品 & & & & & $\sum \pi \square$ & מ & $\begin{array}{l}13 \\
15\end{array}$ & $\begin{array}{r}4 \\
17\end{array}$ & & \\
\hline 通銅 & $\mid 189,285$ & | 平銅竐 & $\begin{array}{r}95 \\
2,940\end{array}$ & & & & & & 129 & 16 & 235 & & \\
\hline 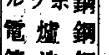 & $\begin{array}{r}37 \\
2,308\end{array}$ & 小形等灙 & 山形銅 & & & & & 蓜㤗用 & 百霄鎆 & $\begin{array}{l}18 \\
19\end{array}$ & $\begin{array}{r}9 \\
9\end{array}$ & & \\
\hline 造銅 & 931 & $\overrightarrow{13 / 4 "}$ & 品 & & & & & 解 & & $\begin{array}{l}24 \\
25\end{array}$ & 1 & & \\
\hline 銅 & 片 & $\begin{array}{l}30^{n m m} \\
40\end{array}$ & $\begin{array}{l}194 \\
614\end{array}$ & & & & & & 塊 & 26 & 1 & & \\
\hline & 11 & 45 & 149 & & & & & Et & 5,65 & 32 & $\mathbf{2}$ & & \\
\hline & 109,991 & tot & 1,437 & & & & & हT & I, J & & 3,038 & & \\
\hline st & | 121,946 & 二 級 & & & & & & & & 厚盖 & 极 & & \\
\hline$\dot{z}-1$ & מיז & $\mid \begin{array}{l}17 / 21 \\
3 \\
3\end{array}$ & $\begin{array}{l}288 \\
15\end{array}$ & & & & & & & $6^{m}$ & 942 & & \\
\hline 部向 & \begin{tabular}{|r|}
8,153 \\
20,696
\end{tabular} & $\begin{array}{l}40 \\
45\end{array}$ & $\begin{array}{l}48 \\
27\end{array}$ & & & & & & & 8 & $\begin{array}{l}194 \\
142\end{array}$ & & \\
\hline If & \begin{tabular}{|l|l|}
288849 \\
\end{tabular} & 㝇 & 118 & & & & & & & 11 & 568 & & \\
\hline
\end{tabular}




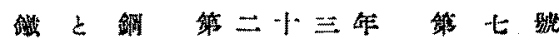

昭和 12 年 5 月中神戸 大阪 撗法三港輸入鈵材品種寸法別数量表

（其の 1）（單位勘）

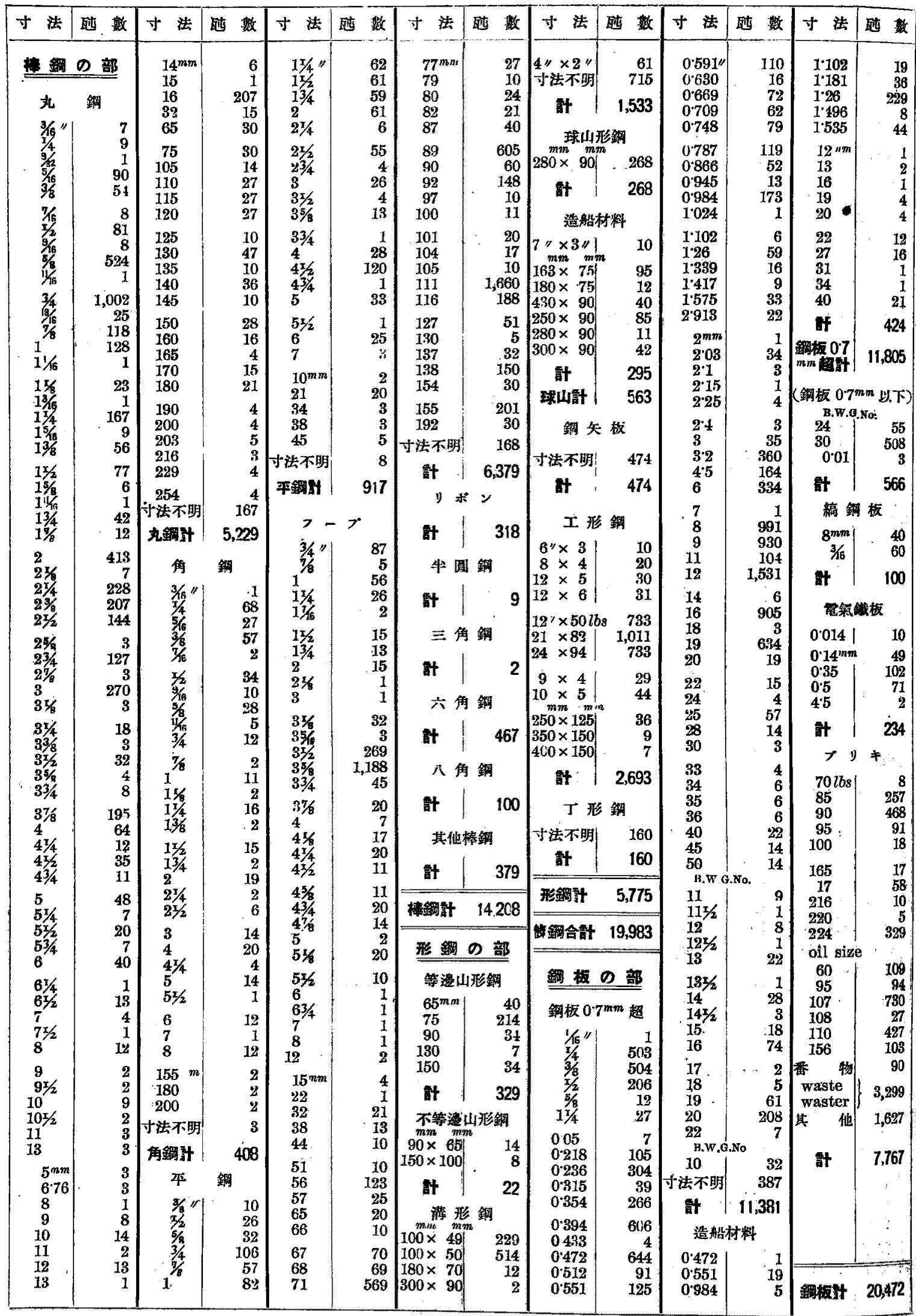




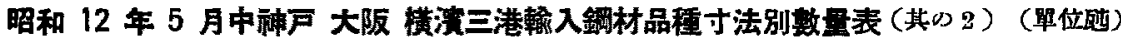

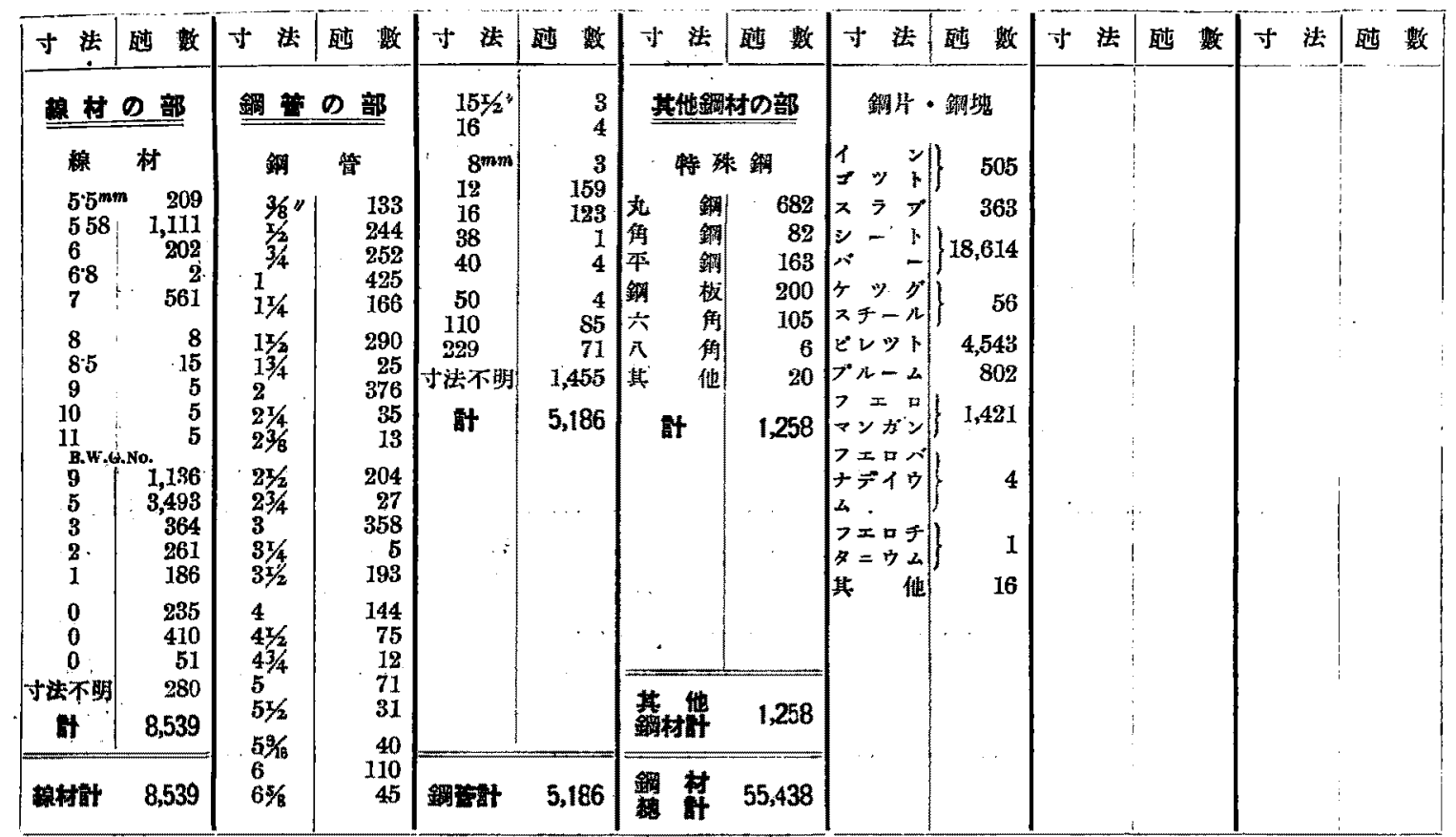

\section{6 月中旬下旬重要鎆材輸入速報}

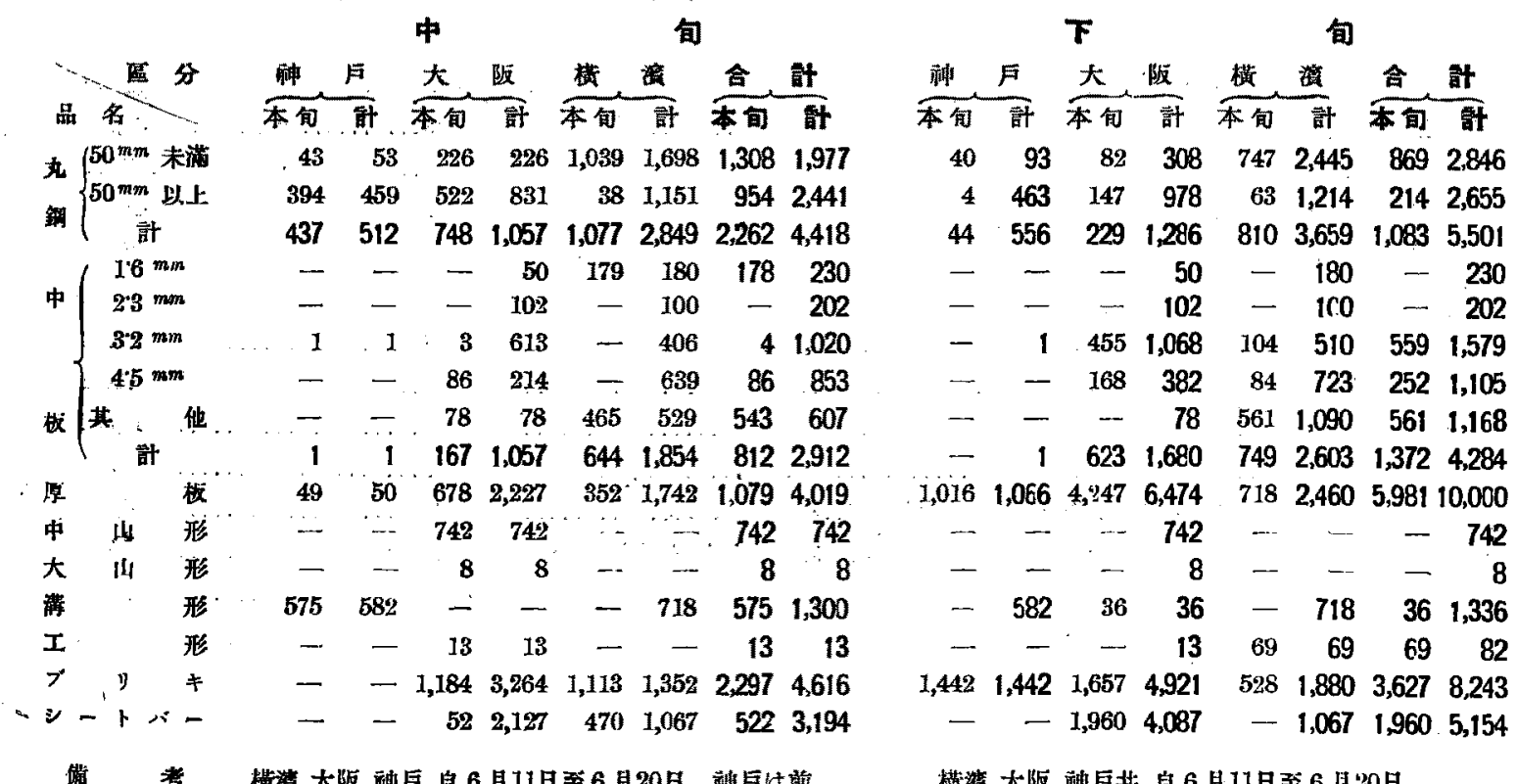

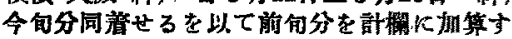




\section{7 年 1 月中满洲國鋼材輸入表}

Quantity : Kilo tons Value: Manchouko Yen

(To-Day Exch. M $100 \quad 100$ )

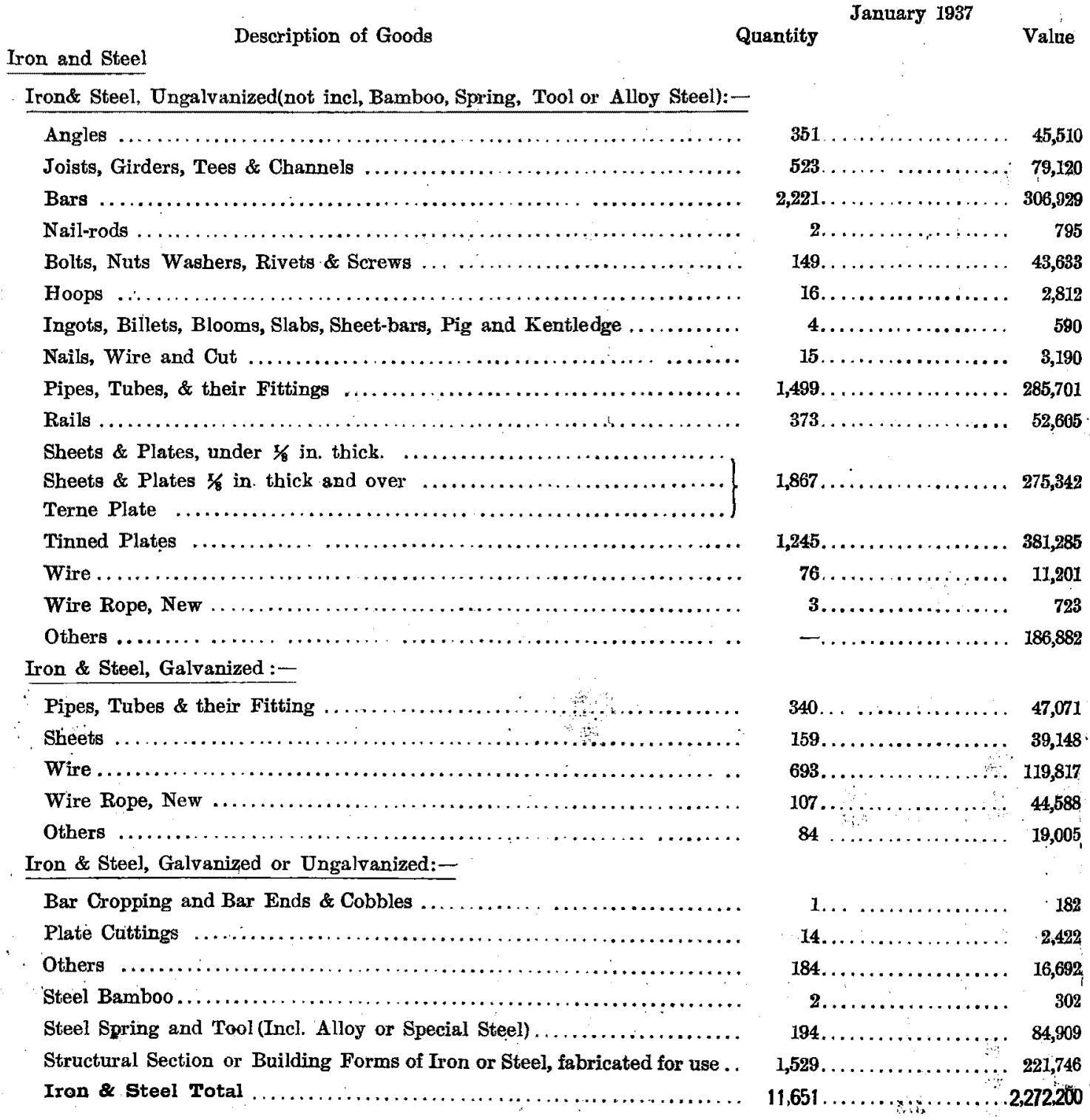




\section{.1937年 2 月中霂洲國銿材翰入表}

Quantity : Kilo tons Value: Manchouko Yen

(To-Days Exch. M. 100 100)

\begin{tabular}{|c|c|c|c|c|}
\hline Description of Goods & $\begin{array}{l}\text { February } 19 \\
\text { Quantity }\end{array}$ & Value & $\begin{array}{l}\text { Total From } \\
\text { Quantity }\end{array}$ & $\begin{array}{l}\text { January } \\
\text { Value }\end{array}$ \\
\hline \multicolumn{5}{|c|}{ Iron \& Steel, Ungalvanized (not incl, Bamboo, Spring, Tool or Alloy Steel):- } \\
\hline Angle & 580. & 83,622 . & 931. & 129,132 \\
\hline Joists, Girders, Tees \& Channels & 2,781 & $360,647 \ldots$ & $3,304 \ldots$ & 439,767 \\
\hline Bars & $2,325 \ldots$ & $311,713 \ldots \ldots$ & $4,546 \ldots \ldots$ & 618,642 \\
\hline Nail-rods $\ldots \ldots \ldots \ldots \ldots, \ldots, \ldots, \ldots, \ldots$ & $1,233 \ldots \ldots$ & 186,661 . & $1,235 \ldots \ldots$ & 127,456 \\
\hline Bolts, Nuts, Washers, Rivets \& Screws ................. & $281 . . . .$. & $96,296 .$. & $433 \ldots \ldots$ & 139,929 \\
\hline 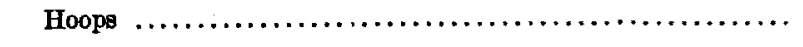 & $18 . . .$. & $4,375$. & $34 \ldots$ & 7,187 \\
\hline Ingots, Billets, Blooms, Blabs, Sheet-bars, & & & & \\
\hline Pig and Kentledge. & $006 \ldots .$. & 6.. & $4 \ldots \ldots$ & 596 \\
\hline Nails, Wire and Cut ... & $46 . \ldots$. & 10,354 & $61 . . .$. & 13,544 \\
\hline Pipes; Tubes, \& their Fittings............................ & $2,223 \ldots$ & $460,921$. & $3,722$. & 752,622 \\
\hline 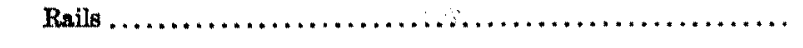 & $518 \ldots$ & $80,694$. & $886 \ldots$ & 133,299 \\
\hline$\cdots)$ & & & & \\
\hline 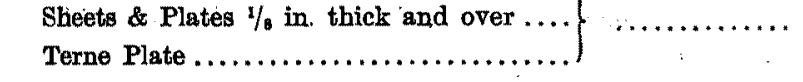 & 3,329. & 58,590 & 196 & 857,932 \\
\hline Tinned Plates.$\ldots \ldots \ldots \ldots \ldots \ldots \ldots \ldots \ldots \ldots$ & 925. & 310,779 & $2,170 \ldots \ldots$ & 692,064 \\
\hline .............. & $170 . \ldots$. & 36,976 . & 246 & 48,177 \\
\hline 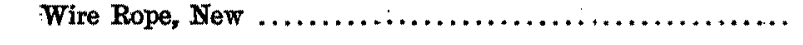 & $-\ldots$. & -. & 3....... & 723 \\
\hline 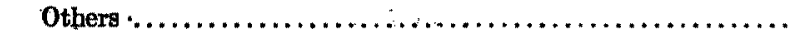 & $-\ldots \ldots$ & $96,388 \ldots \ldots$ & $-\ldots \ldots$ & 283,270 \\
\hline \multicolumn{5}{|l|}{ Iron \& Steel, Galvanized:- } \\
\hline their Fitting & 176 & 27,9 & 516. & 74,972 \\
\hline 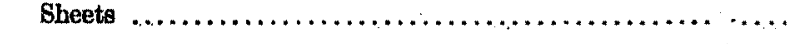 & $184 \ldots \ldots$ & $43,678$. & $343 \ldots \ldots$ & 82,826 \\
\hline 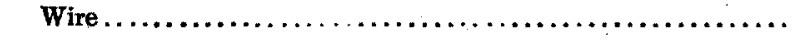 & $1,522 \ldots \ldots$ & $338,132 \ldots \ldots$ & $2,215 \ldots \ldots$ & 452,949 \\
\hline Wire Rope, New $\ldots \ldots \ldots \ldots \ldots \ldots \ldots \ldots \ldots$ & $229 \ldots$ & 85,42 & 336. & 130,012 \\
\hline Others & $1 \ldots$. & 40 , & & 35 \\
\hline \multicolumn{5}{|l|}{ Iron \& Steel, Galvanized or Ungalvanized:- } \\
\hline Ber Cropping and Bar Ends \& Cobbles & 62 & 10,69 & 63 . & 10,875 \\
\hline 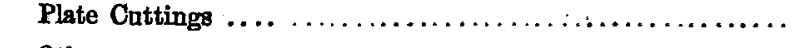 & $31 . . . \ldots$ & $4,592 \ldots \ldots$ & $45 \ldots \ldots$ & 7,014 \\
\hline 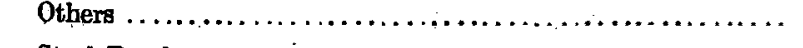 & $37 \ldots \ldots$ & $3,776 \ldots \ldots$ & $221 \ldots \ldots$ & 20,468 \\
\hline Steel Bamboo & $18 \ldots \ldots$ & $4,607$. & $20 . \ldots \ldots$ & 4,909 \\
\hline Steel Spring and Tool (Incl. Alloy or Special Steel) & $\therefore$ & & & \\
\hline $\begin{array}{l}\text { Structural Section or Building Forms of Iron or Steel, }, \\
\text { tabricated for use } \ldots \ldots \ldots \ldots \ldots \ldots \ldots \ldots \ldots \ldots \ldots \ldots\end{array}$ & $\begin{aligned} & 284 \ldots \\
& 1,361 \ldots\end{aligned}$ & $\begin{array}{r}78,454, \ldots \\
436,759 \ldots\end{array}$ & $\begin{array}{r}478 \ldots \\
2,890 \ldots\end{array}$ & $\begin{array}{l}163,363 \\
658,505\end{array}$ \\
\hline eot 1 & 492.. & &, $143 \ldots$ & 09,8 \\
\hline
\end{tabular}




\section{7年 3 月中满洲國鎆材朁入表}

Quantity : Kilo tons Value : Mauchouko Yen

(To-Day Exch. M $100 ¥ 100$ )

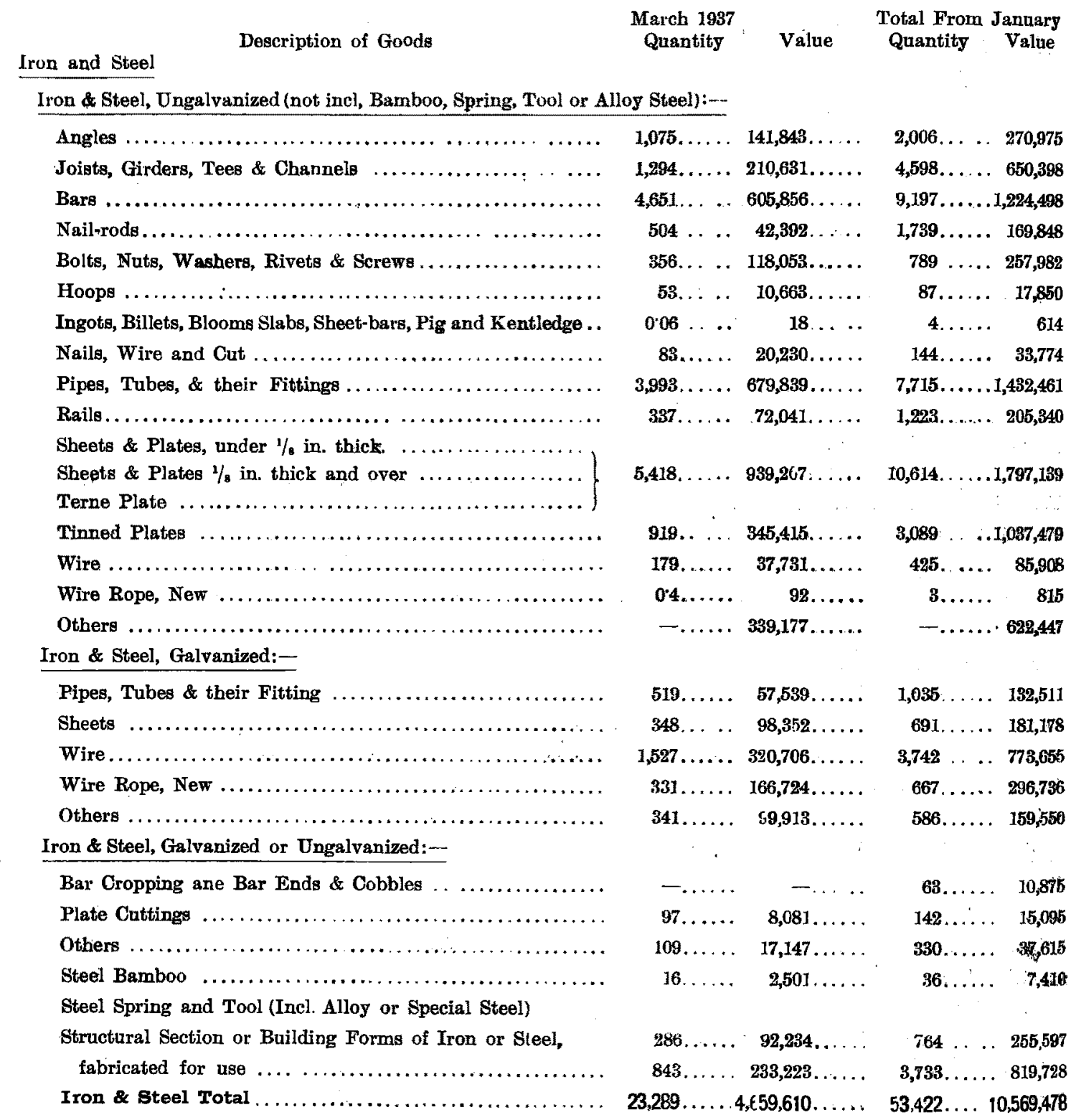


相場 の 部

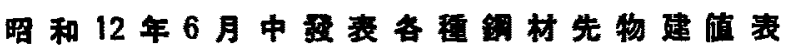

\begin{tabular}{|c|c|c|c|c|c|c|c|c|c|c|}
\hline \multirow{2}{*}{ 所 周 } & \multirow{2}{*}{ 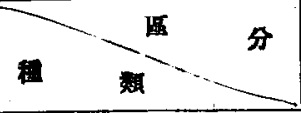 } & \multicolumn{3}{|c|}{ 外歖偍段 } & \multirow{2}{*}{$\begin{array}{l}\text { 建值 } \\
\text { 月日 }\end{array}$} & \multicolumn{2}{|c|}{ 穖 } & \multicolumn{2}{|c|}{ 月 } & \multirow{2}{*}{ 䜤 } \\
\hline & & 沖 管 & 篇 & 河崖着 & & 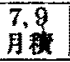 & $\begin{array}{l}7,8 \\
8 \\
\end{array}$ & $\begin{array}{l}8,9 \\
\text { 月栍 }\end{array}$ & $\left|\begin{array}{c}7,8,9 \\
\text { 䅪 }\end{array}\right|$ & \\
\hline 日本粠 & 兀 $\quad\left\{\begin{array}{c}9 \mathrm{~mm} \\
50-75 \mathrm{~mm} \\
80-100 \mathrm{~mm}\end{array}\right.$ & $\left|\begin{array}{c}12-5-0 \\
12-0-0 \\
11\end{array}\right|$ & $\begin{array}{c}3 / 2-0 \\
" 1\end{array}$ & $\begin{array}{c}212 \cdot 25 \\
207 \cdot 97 \\
7\end{array}$ & 6-16 & P & 495 & $\begin{array}{r}\mathrm{PA} \\
195 \\
195 \\
\end{array}$ & $m$ & 据，罱 \\
\hline 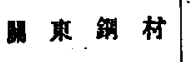 & 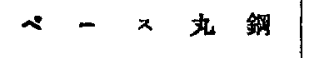 & $11-18-6$ & $1 / 2-0$ & 20669 & $6-17$ & 195 & & & & 据 箁 \\
\hline 日本侴 & 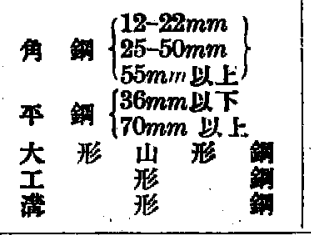 & $\mid \begin{array}{c}11-14-6 \\
" \prime \\
11-17-6 \\
\prime \prime \\
11-15-0 \\
12-7-0\end{array}$ & $\begin{array}{c}1 / 2-0 \\
" 1 \\
" 1 \\
" 1 \\
" 1 \\
" 1\end{array}$ & $\begin{array}{c}203 \cdot 27 \\
y \\
" \prime \\
205 \cdot 83 \\
\prime \prime \\
20 \\
204 \cdot 55 \\
313 \cdot 97\end{array}$ & $\begin{array}{l}\text { 6-16 } \\
\text { "1 } \\
\text { "" } \\
\text { " } \\
\text { " }\end{array}$ & & & $\begin{array}{l}195 \\
195 \\
195 \\
195 \\
195 \\
180 \\
185 \\
190\end{array}$ & & \begin{tabular}{|c} 
据 \\
"䁾 \\
" \\
" \\
" \\
"
\end{tabular} \\
\hline 中形山形共㖥 & 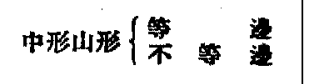 & $\left|\begin{array}{l}11-17-6 \\
12-5-0\end{array}\right|$ & $\stackrel{5 / 2-0}{11}$ & $\begin{array}{l}205 \cdot 83 \\
212 \cdot 24\end{array}$ & ${ }^{6-15}$ & & & $\begin{array}{l}200 \\
210\end{array}$ & & 据 ”置 \\
\hline 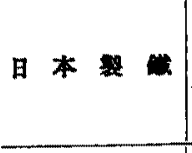 & 小形 $\left\{\begin{array}{l}3 \times 20 \mathrm{~mm} \\
3 \times 25-3 \times 40 \mathrm{~mm} \\
5 \times 40-6 \times 45 \mathrm{~mm}\end{array}\right.$ & $\left|\begin{array}{r|}13-5-0 \\
12-15-0 \\
13-0-0 \\
12-10-0 \\
32-5-0\end{array}\right|$ & $\begin{array}{c}3 / 2-0 \\
" 1 \\
" 1\end{array}$ & $\begin{array}{l}229 \cdot 37 \\
220 \cdot 81 \\
225 \cdot 18 \\
216 \cdot 52 \\
212 \cdot 24 \\
\end{array}$ & $\begin{array}{c}\text { 6-15 } \\
\text { " } \\
\text { " } \\
\end{array}$ & & & $\begin{array}{l}225 \\
215 \\
205 \\
\end{array}$ & & $\begin{array}{c}\text { 据 } \\
\text { ”阅 } \\
\text { " }\end{array}$ \\
\hline 厚板共眼 & 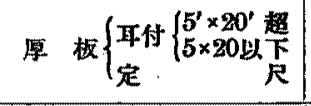 & $\left|\begin{array}{c}14-14-0 \\
" \prime\end{array}\right|$ & $\begin{array}{c}\not z / 2-0 \\
\prime \prime \prime\end{array}$ & $\left|\begin{array}{c}254: 31 \\
" \prime\end{array}\right|$ & $\begin{array}{l}\text { 6-21 } \\
\text { "" }\end{array}$ & & & $\begin{array}{l}205 \\
195 \\
225\end{array}$ & & 据 ”㯰 \\
\hline 中推 & 中 板 $\left\{\begin{array}{l}1 \cdot 6 \mathrm{~mm} \\
2 \cdot 3 \mathrm{~mm} \\
3 \cdot 2 \mathrm{~mm} \\
4 \cdot 5 \mathrm{~mm}\end{array}\right.$ & $\mid$\begin{tabular}{|l|}
$14-12-6$ \\
$14-2-6$ \\
$14-14-6$ \\
$13-19-6$
\end{tabular} & $\begin{array}{c}3:-0 \\
y \\
y\end{array}$ & \begin{tabular}{|l|}
$252 \cdot 92$ \\
$244 \cdot 36$ \\
$254 \cdot 65$ \\
24179
\end{tabular} & "6-15 & & & $\begin{array}{l}240 \\
235 \\
230 \\
225\end{array}$ & & 据 ”䈯 \\
\hline 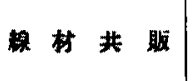 & 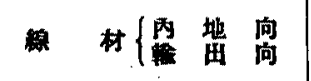 & $13 \div 0-0$ & $2 / 2-0$ & $\underset{17}{223: 90}$ & 6-23 & & & & 200 & 据 㯰 \\
\hline & $>y \neq\left\{\begin{array}{l}170 \mathrm{lb8} \\
200\end{array}\right.$ & $\left|\begin{array}{rr|}8 & 11 \cdot 59 \\
2 & -9-5 \\
8 & 11-98 \\
2 & -11-6\end{array}\right|$ & 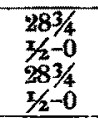 & $\begin{array}{l}40.99 \\
43 \cdot 12 \\
4422 \\
4494\end{array}$ & $6-21$ & & & & $\begin{array}{l}35.50 \\
37.00\end{array}$ & 据，置 \\
\hline & 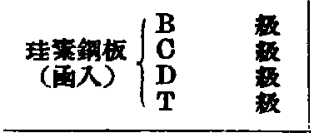 & -1 & $1 / 2-0$ & & $\begin{array}{c}6 \rightarrow-17 \\
" \\
" \\
"\end{array}$ & & & & & 值段發表せず \\
\hline 本 & 薄板 $3^{\prime} \times 6^{\prime}$ & & & & $6 \div 7$ & & & & & 值段登表せず \\
\hline 14 & 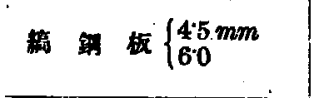 & $\mid 14-10-6$ & $x_{11}^{1 / 2-0}$ & $251 \cdot 46$ & $6-18$ & & & $\begin{array}{l}245 \\
245\end{array}$ & & 据，置 \\
\hline & ス ニップ用筑板 & $18-0-0$ & $3 / 2-0$ & $310 \cdot 73$ & $6-18$ & & & & & 值段酸表せす \\
\hline (w) & 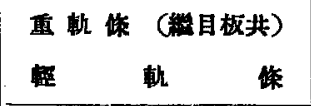 & & & & $\begin{array}{l}5-25 \\
5-3\end{array}$ & & & & & $\begin{array}{ll}\text { 夷回三軌合远 } 210 \text { 圆 } \\
\text { 头回六轨會迄 } 200 \text { 圆 }\end{array}$ \\
\hline & 全 & & & & $5-25$ & & & & & 方回銅矢板會迄 205 圆 \\
\hline & 普通特 珠 & & & & $6--11$ & & & & & 值段發表せず \\
\hline
\end{tabular}




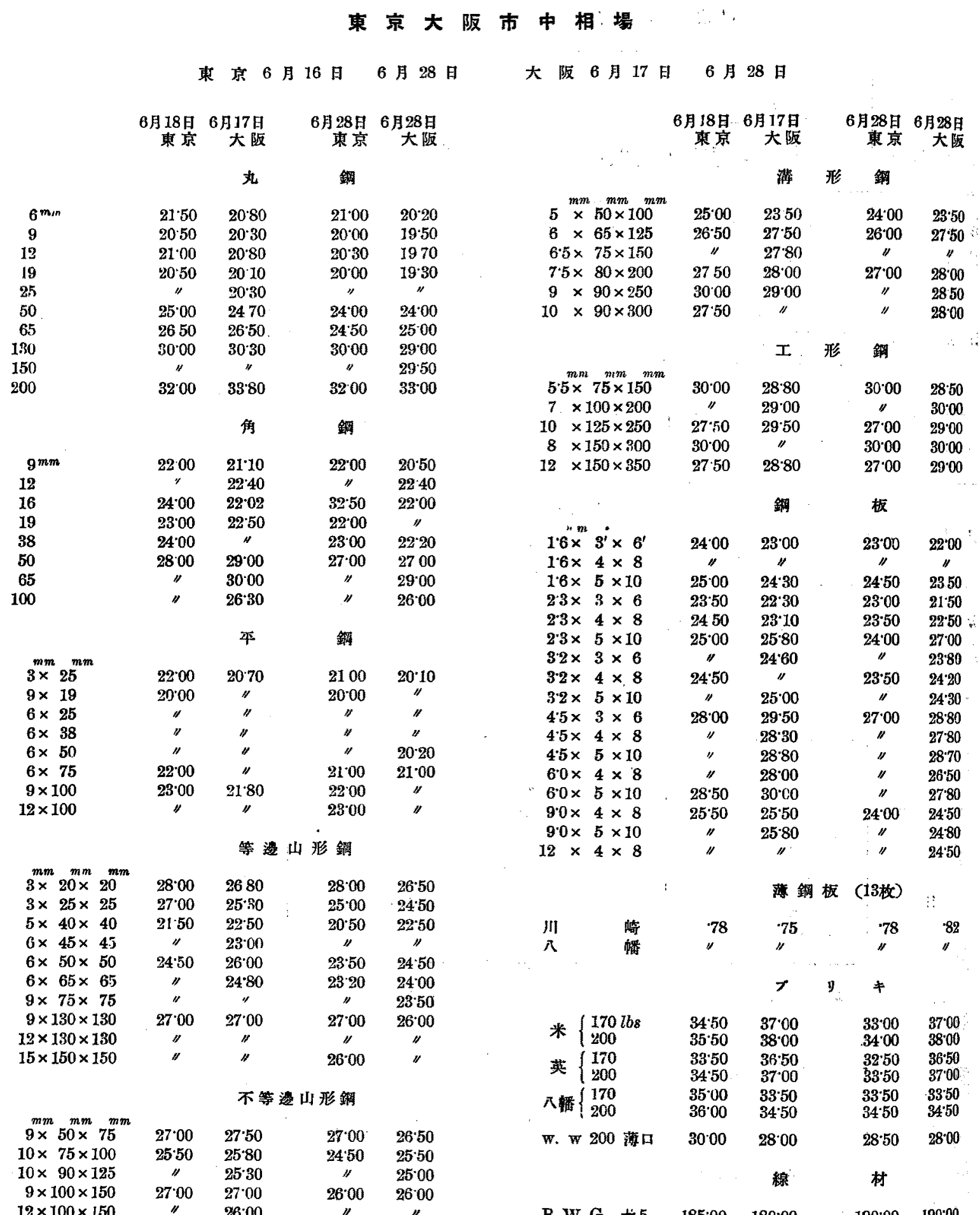

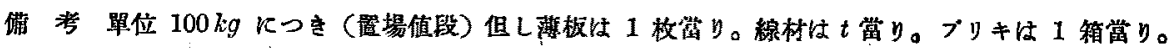

